\title{
SPHAERODACTYLUS GRANDISQUAMIS, A VALID SPECIES
}

\author{
Chapman Grant, Major, United States Army
}

Stejneger ${ }^{1}$ described Sphaerodactylus grandisquamis in 1902 from a series of 47 specimens taken at Luquillo and near Ponce. $\mathrm{He}$ added 9 other specimens from Vieques under this name, altho noting a marked difference in coloration and pattern.

The selection of the name grandisquamis was not a happy one as it calls attention to a trivial and uncertain factor. Unfortunately Dr. Stejneger attributed the sexual dichromatism and markings which are so distinct in this species to individual variation. He did not have a sufficient series to make it apparent to him that this species is larger than macrolepis, nor that grandisquamis is the only species with a distinct white tail tip and a usually perfect scapular "mask".

In 1914 Barbour ${ }^{2}$ says: "This species, [grandisquamis] which had hitherto been confounded with Sphaerodactylus macrolepis Gunther, the type locality of which was St. Thomas, has been shown by Stejneger to be perfectly distinct, yet to have close affinity with Gunther's species. Stejneger's species may easily be separated by its much larger dorsal seales. In its distribution it is confined to Porto Rico and Vieques".

In 1915 ? Fowler ${ }^{3}$ accepts the species without question: "Three from Arecibo Road, Porto Rico, about the $70 \mathrm{~km}$. post; these are similar to Dr. Stejneger's figure, ${ }^{4}$ [this figure is of a female], except that the black scapular blotch has in each example two small pure white spots. Two specimens have the dark spots as more or less broken longitudinal bands, [probably females] though in the remaining example a more speckled appearance is seen and the spots are smaller." Undoubtedly this last is a male.

Again a series too small to make evident the interesting sexual dichromatism and markings of this form.

In 1917 Barbour ${ }^{5}$ says: "Sphaerodactylus macrolepis Gunther. In the collection there are specimens from St. Thomas, Tortola, Virgin Gorda and Anegada. These have been compared with a large series in the M. C.Z. from St. Croix. All belong to the same species; the Anegada specimens are much paler, more ashy, than any of the others and the variation observable in this large number of individuals shows that Sphaerodactylus grandisquamis Stejneger, 
from Porto Rico, distinguished by the larger size of the dorsal scales is really far from conspicuously distinct. The species may perhaps stand, however, since there is no doubt but that the average number of scales upon the dorsal area is slightly fewer."

We must begin to note that there are other things than scale counts which when constant, constitute a species.

In 1920 , Schmidt ${ }^{6}$ lumps the two species together. I have not seen his paper.

In 1921 Barbour ${ }^{7}$ states: "I cannot, with this large material before me, find any stable character separating macrolepis from grandisquamis. Certainly in specimens of equal size the dorsal scales differ but very little in size. In the topotype of macrolepis, figured, they are actually larger than in the specimen of grandisquamis. . ."

Barbour's figures are of females of $S$. macrolepis fig. 2 and $S$. grandisquamis fig. 3. In his description of macrolepis he uses a Porto Rico specimen, i.e. grandisquamis. If we could only get away from scale counting and not let the trees obscure the forest.

In 1928, Schmidt ${ }^{8}$ lumps macrolepis, grandisquamis and monensis. $\mathrm{He}$ shows cuts of a male and a female as "common types of pattern". He proves that by scale count the three species are one. No attention has been paid to color, size, pattern, sexual differences, proportions or habits, which differ and are constant in each of the three species.

In 1930, Barbour ${ }^{9}$ does not list monensis or grandisquamis, allowing macrolepis to answer for the three.

In the July number of this Journal, I reestablished the validity of monensis. I had not seen specimens from St. Croix, so considered them identical with the Porto Rican form. This belief was engendered by the quotations at the beginning of this article. Upon collecting a small series from St. Croix, I immediately realized that the Porto Rico form was distinct, and therefore grandisquamis was valid. The close similarity between the forms from St. Croix, Culebra and Vieques would make my danforthi from Culebra and Vieques of only sub-specific value, if it were not for the fact that I found no red-head males on St. Croix and find no mention of this phase in the literature. A larger series from St. Croix may show the forms from St. Croix, Culebra and Vieques to be sub-specific inter se. My "Chart for Determining the Sphaerodactyls of the Porto Rican Region" in this issue still further brings out the differences between the species.

My opinions are based on fifteen months of constant work in the field where I have observed hundreds of specimens. I have hatched 
out many eggs and observed the young. My study collection at this time contains 228 grandisquamis from Porto Rico and 157 danforthi from Culebra; 63 danforthi from Vieques and 11 macrolepis from St. Croix.

It is my conviction that the specific differences of the Sphaerodactyls of the Porto Rico region should be based on the characters shown in my "Chart" as well as on scale count.

A resume of the outstanding differences between the four species is not amiss here as macrolepis is not included in my "Chart". There are other constant differences between the St. Croix, Vieques and Culebra forms which are omitted here.

\begin{tabular}{|c|c|c|c|c|c|c|c|c|}
\hline - & $\begin{array}{l}\text { White } \\
\text { tail } \\
\text { tip }\end{array}$ & $\begin{array}{l}\text { Av. } \\
\text { aduit } \\
\text { size }\end{array}$ & $\begin{array}{c}\text { Sex } \\
\text { dichro- } \\
\text { matism }\end{array}$ & $\begin{array}{l}\text { Color } \\
\text { above }\end{array}$ & $\begin{array}{c}\text { Head } \\
\text { pattern }\end{array}$ & Chin & $\begin{array}{l}\text { Scarpular } \\
\text { pattern }\end{array}$ & $\begin{array}{l}\text { Red } \\
\text { head } \\
\text { males }\end{array}$ \\
\hline $\begin{array}{l}\text { grandis- } \\
\text { guamis }\end{array}$ & + & 60 & + & Brown & $\begin{array}{l}\text { 의 weak } \\
\sigma^{2} \text { rare }\end{array}$ & $\begin{array}{l}\text { 을 clear } \\
\sigma^{2} \text { spotted }\end{array}$ & $\begin{array}{l}\text { 아 large "mask" } \\
\text { ơ small "mask" }\end{array}$ & - \\
\hline macrolepis.. & - & 50 & + & $\begin{array}{l}\text { ㅇ brown } \\
\sigma^{2} \text { gray }\end{array}$ & Vivid & $\begin{array}{l}\text { Black and } \\
\text { White }\end{array}$ & $\begin{array}{l}\text { 으 small "mask" } \\
\text { ơ very small " } \\
\text { "mask" }\end{array}$ & - \\
\hline danforthi... & - & 50 & + & $\begin{array}{c}o \text { brown } \\
\sigma^{\prime} \text { gray } \\
\text { brown }\end{array}$ & $\begin{array}{l}\text { o vivid } \\
\text { o' rare }\end{array}$ & $\begin{array}{l}\text { Blach \& } \\
\text { White } \\
\text { red-head } \\
\text { clear }\end{array}$ & $\begin{array}{l}\text { 옹 small "mask" } \\
\text { o" very small } \\
\text { "mask" }\end{array}$ & $+F$ \\
\hline monensis.... & - & 50 & - & Gray & Weak .... & White .... & "spectacles" & - \\
\hline
\end{tabular}

\section{NOTES}

1. Leonard Stejneger, The Herpetology of Porto Rico, U.S.N.M. 1904, pp. 602-7.

2. Thomas Barbour, A Contribution to the Zoogeography of the West Indies with especial reference to Amphibians and Reptiles, Mus. C. Z. Vol. XLIV No. 2, March, 1914.

3. Henry W. Fowler, Some Amphibians and Reptiles from Porto Rico and the Virgin Islands. Acad. Sci. Phila. p. 7.

4. Rep. U. S. IMus., 1902, p. 605, fig. 52.

5. Thomas Barbour, Notes on the Herpetology of the Virgin Islands. Pro. Biol. Soc. Wash. Vol. 30, p. 98.

6. K. P. Schmidt, Ann. N. Y. Acad. Sci. p. 184.

7. Thomas Barbour, Sphaerodactylus Mem. Mus. Comp. Zoo. Vol. XLVII, No. 3, pp. 253-5.

8. K. P. Schmidt, Scientific Survey of Porto Rico and the Virgin Islands. N. Y. Acad. Sci. Vol. X, pp. 70-4.

9. Thomas Barbour, A List of Antillean Reptiles and Amphibians, Zoologica, N.Y.Z.S., Vol. XI, No. 4, p. 83. 